\title{
Searching for tunnels of proteins - comparison of approaches and available software tools
}

\author{
Deepti Jaiswal', Radka Svobodová Vařeková, Crina-Maria Ionescu, David Sehnal, Jaroslav Koča \\ From 7th German Conference on Chemoinformatics: 25 CIC-Workshop \\ Goslar, Germany. 6-8 November 2011
}

Tunnels are access paths connecting the interior of molecular systems with the surrounding environment. The presence of tunnels in proteins influences their reactivity, as they determine the nature and intensity of the interaction that these proteins can take part in. A few examples of systems whose function relies on tunnels include transmembrane proteins involved in small molecule transport and signal transduction, peptide exit channels through which ribosomes release newly synthesized proteins during transcription Knowledge of the location and characteristics of protein tunnels can find immediate applications in rational drug design, protein engineering, enzymology etc.

Identification and characterization of tunnels has been the focus of several studies, and various algorithms and software tools have been developed for these purposes [1-4]. These methodologies use special mathematical algorithms to represent and scan the surface of the protein in search for tunnels and the amino acid residues involved.

In the presented study we perform a benchmarking study of the most known approaches and software tools for finding tunnels in proteins (Mole, MolAxis, Hollow, etc.). We focused on proteins from the cytochrome P450 family, which are very important from the biological point of view. We provide a critical discussion of the strong and weak points of the analyzed approaches and software tools.

Published: 1 May 2012

\section{References}

1. Petřek M, Kosinová P, Koča J, Otyepka M: MOLE: a Voronoi diagram-based explorer of molecular channels, pores, and tunnels. Structure 2007, 15:1357-1363.

National Centre for Biomolecular Research and CEITEC - Central European Institute of Technology, Masaryk University, Brno, Czech Republic, 625 00, CZ
2. Ho BK, Gruswitz F: HOLLOW: generating accurate representations of channel and interior surfaces in molecular structures. BMC Struct Biol 2008, 8:49.

3. Yaffe E, Fishelovitch D, Wolfson HJ, Halperin D, Nussinov R: MolAxis: efficient and accurate identification of channels in macromolecules. Proteins 2008, 73:72-86.

4. Petřek M, Otyepka M, Banáš $P$, Kosinová P, Koča J, Damborský J: CAVER: a new tool to explore routes from protein clefts, pockets and cavities. BMC Bioinformatics 2006, 7:316.

doi:10.1186/1758-2946-4-S1-P60

Cite this article as: Jaiswal et al:: Searching for tunnels of proteins comparison of approaches and available software tools. Journal of Cheminformatics 2012 4(Suppl 1):P60.

\section{Publish with ChemistryCentral and every scientist can read your work free of charge \\ "Open access provides opportunities to our colleagues in other parts of the globe, by allowing anyone to view the content free of charge." \\ W. Jeffery Hurst, The Hershey Company. \\ - available free of charge to the entire scientific community \\ - peer reviewed and published immediately upon acceptance \\ - cited in PubMed and archived on PubMed Central \\ - yours - you keep the copyright \\ Submit your manuscript here: \\ http://www.chemistrycentral.com/manuscript/

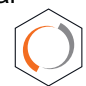 \\ ChemistryCentral}

